\title{
Gender Within The Perspective of Media Law
}

\author{
Ahmad Riyadh U. B. \\ riyadhadvokat@yahoo.com \\ Public Administration Department, Faculty of Social and Political Science \\ Universitas Muhammadiyah Sidoarjo
}

\begin{abstract}
Gender as a social construction that gave birth to dissimilarity, was born through socialization, culture, religion, and state power. The noble principles of Indonesian people since independence on 17th of August 1945 until the present, during 73 years of independence, are still unable to found a harmonious relationship between the press (read: media), government and society (women). This research aims to describe gender roles in the perspective of media law. The research methodology used within this study is a qualitative descriptive approach using inductive thinking and thematic analysis. The outcomes of this research show that there are new findings, namely: The establishment of media must be state incorporated; Women as part of the media community understand the functions of non-press and the press media; and finally the media and women realize that the media world is always in touch with the law as well as the legal vacuity.
\end{abstract}

Keywords: Gender, Law Perspective, Media.

\section{Introduction}

Humans have the ability to clarify their environment through the symbols that are created and standardized through their traditions and cultural systems. This symbolization process is related to the system that we see now as male occupation, can also be seen to be carried by women in other cultural systems. This is due to the dominance of a patriarchal cultural system we are currently living in. Thus, gender between various kinds of people can be different. Gender differences are actually not a problem when it does not cause injustice (gender inequality).

Media (newspapers, radio, and television) as well as new technologies are part of culture and society. Media is widely understood as an effective channel to spread and drive global culture. In countries with high media penetration rates, none of the aspects in their society are sterile from the influence of the media, though with different degrees. Media can also be formulated as a social actor, with the influence and power possessed, for social change. According to Amarthya Sen, poverty has never happened en masse as long as there is still freedom of the press. Though other information providers such as the internet, libraries, national archives or museums cannot be ignored, they also count [1].

Freedom of the press is one of the struggles of the Indonesian people to actualize a democratic state system. The press is the fourth pillar of democracy based upon the Trias Politica theory, where authority lies in the hands of the executive, legislature and judiciary and the press; then the role of the press in maintaining the freedom of the press in a balanced manner and capable of carrying out its functions as media: First, information; second, 
education; third, social control; fourth entertainment; and the fifth, economic institutions, desperately need legal certainty to prevent each party from mutually 'judging'. The government accuses the press of violation, the Press writes without adhering to the Journalistic Code of Ethics, and the Society does violence and even vandalism. During the three years of government administration in the Old Order (1945-1965), the New Order (1966-1998), and the Order of the Reformation (1998-2018), press offenses and general criminal offenses related to news and journalistic works still unable to found a common understanding [2].

During the Old Order the freedom of the press was restricted by the authority control of the country's 'iron fist'. Within the era of guided democracy in the Old Order, the Regulations of the Supreme War (Peperti) Number 10 of 1960 created regulations requiring the press to obtain an issuance permit from the Regional Hazard Authority [3]. Presidential Regulation Number 6 of 1963, which required the press to have a Public Permit (SIT) was also issued [4]. During the Old Order government in Indonesia, the government had carried out anti-freedom measures by banning or closing newspapers 480 times. Even just a one-year 'honeymoon' press with the government, the government through the National Defence Council issued Regulation Number 11 of 1946 concerning Printing, Announcement, and Publishing. Even before the collapse of the Old Order's power, President Soekarno banned the publication of 25 newspapers. One of them is the Waspada Daily Medan, with the reason that it cannot save the president's political power and interests [5].

It can be concluded that the political system of the Old Order era was a non-free press system. The Indonesian government predominantly uses authoritarian and communist press theory approaches [5]. Even President Soekarno in a speech at the general meeting of the Indonesian Journalists Association (PWI) on the 19th anniversary of independence, published by the New York Times, stated that:

"...I firmly declare now that in a revolution there must be no freedom of the press. Only the press supports the revolution that is permissible to live," he said. "The hostile press towards the revolution must be removed" [5].

During the New Order the Indonesian Government issued Press Law No. 11 of 1966 and Regulation of the Minister of Information Number 03/Per/Menpen/1969, which still required the issuance of the press to have a Public License (SIT). In addition, on 1st of August, 1973 the Commander of the Safety and Order Command (Pangkopkamtib) with Decree No. Kep 063/PK/IC/VIII/1973 requires that all press releases, newspapers and magazines must have a Print Permit (SIC).

The freedom of the press was increasingly restrained, when the New Order Government declared its position through the issuance of the Press Main Law (UUPP) Number 21 of 1982, which rearranged the obligations of the Issuance Permit (SIT) and Press Issuance Business License (SIUPP). Strengthening UUPP, Minister of Information issued Permenpen No. 01 of 1984 that requires the issuance of press to have SIUPP. The media industry in Indonesia since the Reformation Era in 1999 when it gave birth to Law No. 40 of 1999 regarding the Press, then the development of media, including those that relating to women, experienced extraordinary development and progress [5]. The freedom to use the media, both press and non-pers media, turned out to cause many problems.

According to the UN's Universal Declaration of Human Rights Article 19 that "everyone has the right to express their opinions". There are no sources in the current document. That a threat, which is very harmful to media independence from business problems. Media privatization in the form of restraining press freedom, and capital can disrupt media coverage. "Freedom of the press is a common knowledge for the community to make people happy" [6]. 
Amendments of the 1945 Constitution provide reinforcement by including article 28F, that. 'Everyone has the right to communicate and obtain information to develop their personal and social environment, and has the right to seek, obtain, possess, store, process and convey information using all available channels.

Although in the Article 4 of Reformation Order, regarding with the Press Law clearly states, (1) Freedom of the press is guaranteed as a human right of citizens. (2) The national press is not subject to censorship, banning or prohibition of broadcasting. (3) To guarantee press freedom, the national press has the right to seek, obtain and disseminate ideas and information. (4) In taking responsibility for reporting in front of the law, journalists have a Refuse Right. However, in the midst of the enthusiasm for freedom of the press, the threat to journalists and media companies or the national press has increased [7].

Furthermore, talking about the media in terms of institutions will also reveal an implicit organizational structure that is patriarchal in nature. In organizations, gender inequality often occurs due to the existence of capitalist values and mutually beneficial patriarchal values. Although in quantity there is an increase in the number of women involved in the media industry, it does not eliminate the fact that there is a tendency towards stereotyping, discrimination and even male domination of women in the structure of the media work organization. Therefore, it is necessary to look at the dynamics of gender roles in the perspective of media law in Indonesia.

\section{Methods}

In this research using a type of qualitative research with basic research of descriptive type that is useful for developing knowledge about gender in the perspective of media law. Regarding the objective of the research, the steps that must be carried out by the researcher are as follows; (1) choosing and preparing informants; (2) analyzing data by focusing on relevant themes; (3) Writing themes as a result of interviews with speakers in constructive writing. Combining themes into the research focus in accordance with the research objectives as a title. For this research has a flexible structure and framework. With the hope of being able, in fully and comprehensively describe the phenomenon under study as described in the focus of the study [8].

\section{Results}

\subsection{Woman and Social Media}

The era of gender equality (roles equality of women) in various developments and advancements in all fields in Indonesia, specifically in understanding the law or legal perspective, Indonesia recorded an extraordinary leap, in giving roles to women in various fields, although it is still far behind the role of men. However, efforts to encourage the role of women continue to be carried out, including the obligation to give a portion of women's representation in the political sector as much as $30 \%$, even though it has not been fulfilled consistently. Likewise the representation of women in the government ranging from ministers, governors, regents and mayors. 
Since Maria Santoso, the Minister of Social Affairs (12th of March 1946 until 26th of June 1947) during the Sutan Sjahrir Administration, 34 Indonesian women have become ministers to Jokowi's Kabinet Kerja.

The 2018 Regional Head Election was also attended by female candidates in various electoral districts. From the data compiled by Kompas.com and processed by researchers, there were 14 women who were elected as regional heads, both in sphere of city, district, and provincial levels [9]. Who are they? (1) Dewi Handjani, Dewi was elected as a Regent of Tanggamus, Lampung Province, with sum of 170,570 votes. (2) Ade Munawaroh Yasin, Ade who paired with Iwan Setiawan won the Bogor Regency Election with the total acquisition of 192,221 votes. (3) Anne Ratna Mustika, Anne who was elected as the Purwakarta Regent, is the wife of the current Purwakarta Regent, Dedi Mulyadi. (4) Ade Uu Sukaesih, Ade was elected as Mayor of Banjar with the acquisition of 58,020 votes. (5) Umi Azizah, Umi is the Regent of Tegal. This couple received 518,017 votes and won a landslide victory over 2 other pairs.

(6) Khofifah Indar Parawansa, Khofifah along with her partner, Emil Dardak, won the 2018 East Java Governor Election. (7) Puput Tantriana Sari, Puput was the incumbent regent in Probolinggo District who won the 2018 regional election again. (8) Mundjidah Wahab, Mundjidah was elected as Regent of Jombang after getting 234,971 votes in 2018 regional election with her partner, Sumrambah. (9) Anna Mu'awanah, Anna was elected as Regent of Bojonegoro with the acquisition of 236,358 votes. (10) Ika Puspitasari, Ika Puspitasari and her partner Achmad Rizal Zakaria, were elected in the 2018 Simultaneous Local Election as Mayor and Deputy Mayor of Mojokerto with the acquisition of 23,644 votes.

(11) Iti Octavia Jayabaya, Iti is the incumbent's regent in Lebak Regency, Banten. She was re-elected with her old partner, Ade Sumardi, with the total of 453,938 votes. (12) Paulina Haning-Bullu, Paulina managed to win the seat of Rote Ndao Regent with her partner, Stefan M. Saek by pocketing 22,098 votes. (13) Erlina, Erlina won the regent seat seizure with the acquisition of 54,945 votes. (14) Tatong Bara Tatong is the incumbent mayor in Kotamobagu, North Sulawesi. She won again with the acquisition of 37,408 votes. Data can be shown in Figure 1.

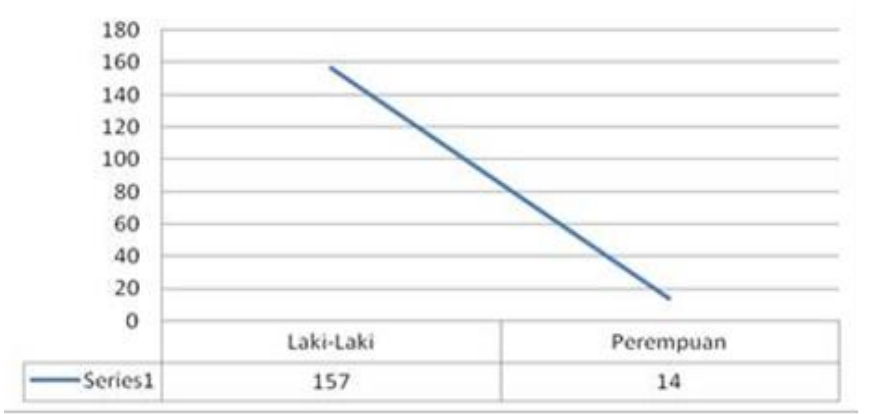

Fig. 1. Simultaneous Regional Election in 2018 Based on Gender

Women and the media are more prominent and even dominate the modern business world through start-up, Indonesia has tracked in the history of the world of women's development by using the advancement in the technology of online media or social media or cyber media, at least 9 women become start-ups. Data can be shown in Table 1. 
Table 1. List of 9 Women Become Start-Ups in Indonesia

\begin{tabular}{cll}
\hline No & \multicolumn{1}{c}{ Name } & \multicolumn{1}{c}{ Business Type } \\
\hline 1. & Catherine Hindra Sutjahyo & Shopping Center Fashion Online Zalora \\
\hline 2. & Cynthia Tenggara & Cathering service of Berrykitchen, \\
\hline 3. & $\begin{array}{l}\text { Claudia Wijaya dan Yenti } \\
\text { Elizabeth }\end{array}$ & $\begin{array}{l}\text { Berry Benka, } \text { e-commerce, all women's and men's } \\
\text { equipments }\end{array}$ \\
\hline 4. & Diajeng Lestari & $\begin{array}{l}\text { HijUp, } \text { e-commerce, fashion and accessories for } \\
\text { Indonesian Moslem }\end{array}$ \\
\hline 5. & Donna Lesmana, & lingerie online Donna store, Lolalola \\
\hline $\mathbf{6 .}$ & Grace Tahir & Online Doctors \\
\hline 7. & Nabilah Alsagoff & Doku Online \\
\hline 8. & Veronika Linardi & $\begin{array}{l}\text { website offering salary information in Indonesia } \\
\text { companies }\end{array}$ \\
\hline 9. & Aulia Halimatussadiah & Founder of online bookstore Kutukutubuku \\
\hline
\end{tabular}

The research results of the Indonesian Internet Service Providers Association (APJII) and the Centre for Communication Studies at the University of Indonesia (UI) in 2014, stated that the majority of users are internally productive between 18-25 years. Users in this proactive age control nearly $49 \%$ or around 44 million, out of a total of 88.1 million.

APJII's press release, on 26th of March 2015 stated that the segment of internet users in Indonesia are those who fall into the category of digital natives. A common understanding can be drawn that digital natives are a generation born after the 1980s, when the internet indeed began to be used widely in the community.

\subsection{Media and Women Exploitation}

The exploitation of women is obviously apparent through various advertisements or promotions via outdoor media; women have always been the main image to attract the attention and views of society broadly. The concept of strengthening this kind of culture, according to researchers, still places women as a marginalized/marginalized part in terms of equality of publications, in aspect of delivering communication, in field of delivering business or trade promotion, in providing positions and authority. This is a concrete portrait of women's exploitation [10].

The most menonon exploitation of women is among the symbols that have been so close to the stamp against women, stereotypes (cooking, preening, bearing child), violence, marginalization, subordination, and excessive workload. Violence against women is always prominent, although marginalization and subordination in some places is still a culture that harms women.

Controversies regarding with the role of gender in Indonesia have begun to shift into a habit or necessity, so that it has gradually transformed into a tradition, so that stereotype symbols (cooking, preening, bearing child) have started to turn into star-up women by utilizing various media. Likewise, violence against women since the Law on Domestic Violence has undergone a total change. Whereas marginalization, subordination, and excessive workloads adjust the needs and abilities of women, experiencing shifts, particularly in big cities.

The outcomes of research in several printed, electronic, and online media in major cities illustrate that every news is related to women, so the photos or images of women are always highlighted, especially in certain parts. Even television as the most favoured spectacle by the 
people of Indonesia, in various programs that are able to rank on the top 10, regularly exhibits the role of women with various forms of exploitation, except live football, the program that reeks of stand-up comedy (jokes) and divination or mystique.

\section{Conclusion}

The outcomes of this research found that the development of advertisement, non-press and press media in the future, which is desperately needed a new model, namely: The establishment of media must be state-incorporated; Women as part of the media community understand the functions of non-press and the press media; and lastly, the media and women understand that the media world is always in touch with the law as well as the legal vacuity. Consequently, this study found a New Model of Media Development for Collective Understanding between Media, Government and Society (Women) within Legal Perspective as follows: First, Press and Non-Media Media must be incorporated. Second, journalistic work products must be accomplished through the Press Law and the Journalistic Code of Ethics. Third, product works related to non-media content must be accomplished with relevant laws and regulations. Specific distribution in cyberspace (online) shall be processed through the ITE Law. Fourth, Content in accordance with the Laws and Regulations must be stated in the Agreement and Guidelines. Fifth, the difference in content according to the Understanding and Guidelines is resolved through deliberation and/or mediation. Sixth, Violations of the Understanding and Guidelines are the competency of the authorities. And lastly, seventh, competent journalistic content and social as well as economic work that meets the standards, gets legal certainty resolved without going through a legal process.

\section{References}

[1] I. Hutagalung, "The System Dynamics of Journalistic in Indonesia," J. Interak., vol. II, pp. 53-60.

[2] Abrar, Indonesian Press Guidelines. Yogjakarta: Pustaka Pelajar.

[3] O. S. M. M. Adji and Law, No Title. Jakarta: Erlangga.

[4] M. Harijanto, "Journalist Legal Protection in Reporting The Government and Society," Law J., vol. II, pp. 1-15.

[5] E. C. Smith, The History of Journalistics Restraint in Indonesia. Jakarta: Penerbit Grafiti Pers.

[6] K. Harahap, "The Dynamics of Journalistic Freedom in Indonesia. Bandung: PT Grafiti Pers.”.

[7] D. Hill, "The Press in New Order Indonesia. Sheffield (UK): Equinox Publishing." .

[8] J. W. Creswell, Research Design of Qualitative, Quantitative and Mixed Method Approaches. Yogjakarta: Pustaka Pelajar.

[9] Kompas.com, "No Title.".

[10] J. D. Lay, "A Critique of Feminist Theory. Indiana University School of Social Work," in Advances in Social Work, vol. 8, pp. 49-61. 